\title{
Effects of $\mathrm{Ce}$ over $\mathrm{TiO}_{2}$ supported $\mathrm{MnO}_{x}$-based Catalyst for $\mathrm{NO}_{x}$ Reduction by Ammonia
}

\author{
Zhi Liu, and Yunqi Liu* \\ State Key Laboratory of Heavy Oil Processing, China University of Petroleum, Qingdao 266580, China
}

\begin{abstract}
Ce modified $\mathrm{MnO}_{\mathrm{x}}$-based catalysts have attracted much attention due to its high activity for selective catalytic reduction of $\mathrm{NO}_{x}$ by $\mathrm{NH}_{3}\left(\mathrm{NH}_{3}-\mathrm{SCR}\right)$ at low-temperatures. However, the most important role of $\mathrm{Ce}$ on the $\mathrm{NH}_{3}-\mathrm{SCR}$ performance of $\mathrm{MnO}_{\mathrm{x}}$-based catalysts has not been confirmed. Herein, the typical $\mathrm{Ce}-\mathrm{Mn} / \mathrm{TiO}_{2}$ catalyst was synthesized through incipient-wetness impregnation method, the positive role of $\mathrm{Ce}$ on $\mathrm{Ce}-\mathrm{Mn} / \mathrm{TiO}_{2}$ catalyst in the $\mathrm{NH}_{3}-\mathrm{SCR}$ process was revealed by combining different activity tests (including $\mathrm{NO}$ oxidation and $\mathrm{NH}_{3}$ oxidation) and characterizations (including XRD, XPS and He-TPDMS experiments). It was found that the introduction of $\mathrm{Ce}$ can promote the dispersion of $\mathrm{MnO}_{\mathrm{x}}$ on $\mathrm{TiO}_{2}$ support. Meanwhile, the doping of $\mathrm{Ce}$ in $\mathrm{MnO}_{\mathrm{x}}$ can also increase the content of $\mathrm{Mn}^{4+}$ species. The $\mathrm{Mn}^{4+}$ species plays a crucial role in NO oxidation reaction, which can trigger the "Fast SCR" reaction and promote the conversion of $\mathrm{NO}_{\mathrm{x}}$. This work provides insight into the catalyst design for $\mathrm{NH}_{3}-\mathrm{SCR}$ process at low-temperature.
\end{abstract}

\section{Introduction}

Nitrogen oxide $\left(\mathrm{NO}_{\mathrm{x}}\right)$, as one of the primary atmospheric pollutants, has attracted much attention for its harm on humans and the environment. Selective catalytic reduction of $\mathrm{NO}_{\mathrm{x}}$ by $\mathrm{NH}_{3} \quad\left(\mathrm{NH}_{3}-\mathrm{SCR}\right)$ has been considered to be one of the most effective deNO technology, and the core of this process lies in the catalyst [1]. The traditional $\mathrm{NH}_{3}-\mathrm{SCR}$ catalyst used in the power plant is composed of $\mathrm{V}_{2} \mathrm{O}_{5}-\mathrm{WO}_{3} / \mathrm{TiO}_{2}$, and its suitable working temperature is between $300{ }^{\circ} \mathrm{C}$ and $400{ }^{\circ} \mathrm{C}$ [2]. However, the applicable temperature of the traditional catalyst is much higher than the flue gas temperature in cement, iron and steel, and other industries [3]. Developing low-temperature $\mathrm{NH}_{3}$-SCR catalyst $\left(<200{ }^{\circ} \mathrm{C}\right)$ is significance.

$\mathrm{MnO}_{\mathrm{x}}$-based catalysts have been widely investigated for their excellent $\mathrm{NH}_{3}$-SCR activity at low-temperature, especially after the modification of Ce element [4-6]. There are many efforts on developing effective Ce-Mn based catalysts and finding the promotion of $\mathrm{Ce}$ on $\mathrm{NH}_{3}-$ SCR process [7-9]. However, the most important role of Ce on improving the $\mathrm{NH}_{3}-\mathrm{SCR}$ performance of $\mathrm{MnO}_{\mathrm{x}}$ based catalysts has not been confirmed.

In this work, a series of $\mathrm{Mn} / \mathrm{TiO}_{2}, \mathrm{Ce} / \mathrm{TiO}_{2}$ and $\mathrm{Ce}-$ $\mathrm{Mn} / \mathrm{TiO}_{2}$ catalysts were synthesized by incipient-wetness impregnation method using anatase $\mathrm{TiO}_{2}$ as support. Ce$\mathrm{Mn} / \mathrm{TiO}_{2}$ exhibits much better $\mathrm{NH}_{3}$-SCR activity than $\mathrm{Mn} / \mathrm{TiO}_{2}$ and $\mathrm{Ce} / \mathrm{TiO}_{2}$. Combined with different activity tests (including $\mathrm{NO}$ oxidation and $\mathrm{NH}_{3}$ oxidation) and characterizations (including XRD, XPS and He-TPD-MS experiments) data, the positive role of Ce element on Ce$\mathrm{Mn} / \mathrm{TiO}_{2}$ catalyst in the $\mathrm{NH}_{3}-\mathrm{SCR}$ process was revealed.

\section{Experimental}

\subsection{Catalysts preparation}

The $\mathrm{TiO}_{2}(5-10 \mathrm{~nm}$, anatase $), 50$ wt. $\% \mathrm{Mn}\left(\mathrm{NO}_{3}\right)_{2}$ solution and $\mathrm{Ce}\left(\mathrm{NO}_{3}\right)_{3} \cdot 6 \mathrm{H}_{2} \mathrm{O}$ were purchased from Aladdin, and used without further purification. The $\mathrm{Mn} / \mathrm{TiO}_{2}, \mathrm{Ce} / \mathrm{TiO}_{2}$ and $\mathrm{Ce}-\mathrm{Mn} / \mathrm{TiO}_{2}$ catalysts were synthesized through incipient-wetness impregnation method. After impregnating $10 \mathrm{~h}$ at room temperature, the samples were dried at $120{ }^{\circ} \mathrm{C}$ for $10 \mathrm{~h}$, followed by calcination at $500{ }^{\circ} \mathrm{C}$ for $4 \mathrm{~h}$. The molar ratio of $\mathrm{Mn} / \mathrm{Ti}$ in both $\mathrm{Mn} / \mathrm{TiO}_{2}$ and $\mathrm{Ce}-\mathrm{Mn} / \mathrm{TiO}_{2}$ catalysts are 0.14 , and molar ratio of $\mathrm{Ce} / \mathrm{Ti}$ in both $\mathrm{Ce} / \mathrm{TiO}_{2}$ and $\mathrm{Ce}-\mathrm{Mn} / \mathrm{TiO}_{2}$ catalysts are 0.02 .

\subsection{Catalytic performance test}

The reactant gases of $\mathrm{NH}_{3}$-SCR process are listed as below: $0.06 \% \mathrm{NO}, 0.06 \% \mathrm{NH}_{3}, 5 \% \mathrm{O}_{2}$, and balanced by $\mathrm{N}_{2}$. The reactant gases of $\mathrm{NO}$ oxidation process are listed as below: $0.06 \% \mathrm{NO}, 5 \% \mathrm{O}_{2}$, and balanced by $\mathrm{N}_{2}$. The reactant gases of $\mathrm{NH}_{3}$ oxidation process are listed as below: $0.06 \% \mathrm{NH}_{3}, 5 \% \mathrm{O}_{2}$, and balanced by $\mathrm{N}_{2}$. The gas hourly space velocity (GHSV) of all the tests were $30000 \mathrm{~h}^{-1}$. The $\mathrm{NO}$ and $\mathrm{NO}_{2}$ contents were detected by an MRU OPTIMA 7 analyzer. The $\mathrm{NO}_{\mathrm{x}}$ conversion, NO to $\mathrm{NO}_{2}$ conversion and $\mathrm{NO}_{\mathrm{x}}$ content in exhaust can be calculated as follows:

$$
\mathrm{NO}_{\mathrm{x}} \text { conversion }=\frac{\left[\mathrm{NO}+\mathrm{NO}_{2}\right]_{\text {in }}-\left[\mathrm{NO}+\mathrm{NO}_{2}\right]_{\mathrm{out}}}{\left[\mathrm{NO}+\mathrm{NO}_{2}\right]_{\text {in }}} \times 100 \%
$$

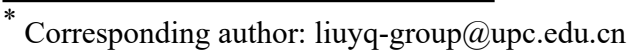




$$
\begin{aligned}
& \mathrm{NO} \text { to } \mathrm{NO}_{2} \text { conversion }=\frac{\left[\mathrm{NO}_{2}\right]_{\text {out }}-\left[\mathrm{NO}_{2}\right]_{\text {in }}}{[\mathrm{NO}]_{\text {in }}} \times 100 \% \\
& \mathrm{NO}_{\mathrm{x}} \text { content in exhaust }=\frac{\left[\mathrm{NO}+\mathrm{NO}_{2}\right]_{\text {out }}}{\left[\mathrm{NH}_{3}\right]_{\text {in }}} \times 100 \%
\end{aligned}
$$

\subsection{Catalyst characterization}

X-ray diffraction (XRD) was conducted on a PANlytical X'Pert PRO MPD X-ray Diffractometer. X-ray photoelectron spectroscopy (XPS) was detected by a VG ESCALABMK II spectrometer using an $\mathrm{Al} \mathrm{K}_{\alpha}$ (1486.6 $\mathrm{eV}$ ) photon source. Temperature-programmed desorption under $\mathrm{He}$ flow (He-TPD) was conducted on a Micromeritics AutoChem 2950 HP instrument, and the desorbed or composed $\mathrm{O}_{2}$ was simultaneous detected by a mass spectrometer (MS, OMNIStar).

\section{Results and discussion}

\subsection{Catalytic activity test}

The results of the $\mathrm{NH}_{3}$-SCR activity tests over $\mathrm{TiO}_{2}$ support, $\mathrm{Mn} / \mathrm{TiO}_{2}, \mathrm{Ce} / \mathrm{TiO}_{2}$ and $\mathrm{Ce}-\mathrm{Mn} / \mathrm{TiO}{ }_{2}$ are presented in Fig. 1. Compared with $\mathrm{Ce}-\mathrm{TiO}_{2}, \mathrm{Mn}-\mathrm{TiO}_{2}$ catalyst showed good SCR $\operatorname{deNO}_{x}$ activity at lowtemperatures, which can reach $95 \% \mathrm{NO}_{\mathrm{x}}$ conversion at $160{ }^{\circ} \mathrm{C}$. The introduction of $\mathrm{Ce}$ can further significantly improve the deNO $\mathrm{N}_{\mathrm{x}}$ activity at low-temperatures, and its $\mathrm{NO}_{\mathrm{x}}$ conversion can reach $95 \%$ at $100{ }^{\circ} \mathrm{C}$.

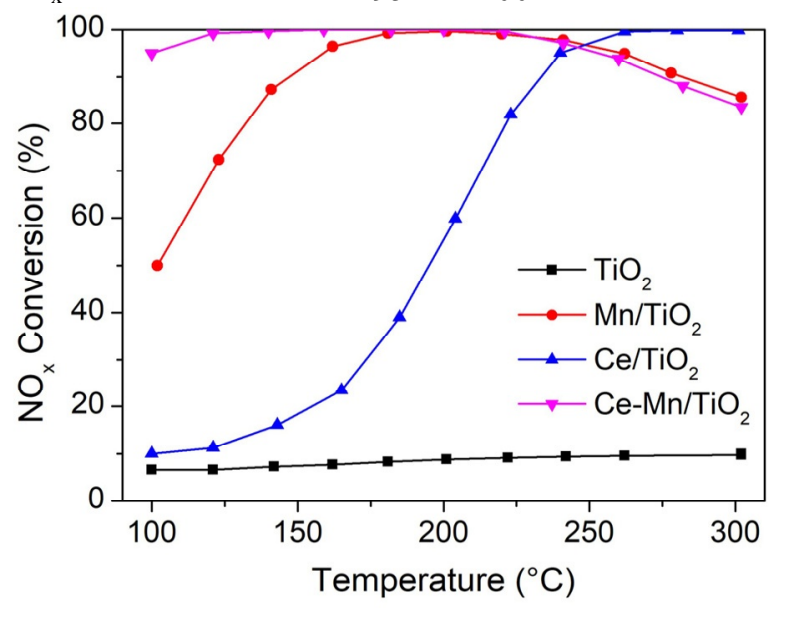

Fig. 1. $\mathrm{NH}_{3}-\mathrm{SCR}$ activity test curves.

As our previous reports [10-12], the $\mathrm{NH}_{3}-\mathrm{SCR}$ reaction $\left(4 \mathrm{NH}_{3}+4 \mathrm{NO}+\mathrm{O}_{2} \rightarrow 4 \mathrm{~N}_{2}+6 \mathrm{H}_{2} \mathrm{O}\right)$ at lowtemperatures can be considered as the coupling of $\mathrm{NO}$ oxidation ( $2 \mathrm{NO}+\mathrm{O}_{2} \rightarrow 2 \mathrm{NO}_{2}$ ) and "Fast SCR" reaction $\left(2 \mathrm{NH}_{3}+\mathrm{NO}+\mathrm{NO}_{2} \rightarrow 2 \mathrm{~N}_{2}+3 \mathrm{H}_{2} \mathrm{O}\right)$, where the "Fast $\mathrm{SCR}$ " reaction can occur rapidly. Therefore, the $\mathrm{NO}$ oxidation activity of catalyst could determine its $\mathrm{NH}_{3}$ SCR activity. To prove this point, NO oxidation activity tests were further tested. As shown in Fig. 2, the order of $\mathrm{NO}$ oxidation activities as follow: $\mathrm{Ce}-\mathrm{Mn} / \mathrm{TiO}_{2}>$ $\mathrm{Mn} / \mathrm{TiO}_{2}>\mathrm{Ce} / \mathrm{TiO}_{2}>\mathrm{TiO}_{2}$, in consistence with the order of their $\mathrm{NH}_{3}-\mathrm{SCR}$ activities. These indicate that the introduction of $\mathrm{Ce}$ can increase the $\mathrm{NO}$ oxidation activity of $\mathrm{Ce}-\mathrm{Mn} / \mathrm{TiO}_{2}$, thus leading to its high $\mathrm{NH}_{3}$-SCR activity at low-temperatures. Although the oxidizing ability of catalysts can promote the NO oxidation activity and $\mathrm{NH}_{3}$-SCR activity at low-temperatures, it can also lead the $\mathrm{NH}_{3}$ oxidation at high-temperatures. The results of $\mathrm{NH}_{3}$ oxidation tests over the four samples are shown in Fig. 3. $\mathrm{NH}_{3}$ began to be oxidized to $\mathrm{NO}_{\mathrm{x}}$ at $230{ }^{\circ} \mathrm{C}$ over $\mathrm{Mn} / \mathrm{TiO}_{2}$ and $\mathrm{Ce}-\mathrm{Mn} / \mathrm{TiO}_{2}$ samples, which can explain the $\mathrm{NH}_{3}-\mathrm{SCR}$ deNO $\mathrm{N}_{\mathrm{x}}$ activity start to decrease since $230{ }^{\circ} \mathrm{C}$. Therefore, the oxidizing ability of low-temperature SCR catalyst is a double-edged sword, which can increase the $\mathrm{NO}_{\mathrm{x}}$ conversion by promoting $\mathrm{NO}$ oxidation at low-temperatures and decrease the $\mathrm{NO}_{\mathrm{x}}$ conversion by promoting the $\mathrm{NH}_{3}$ oxidation at hightemperatures.

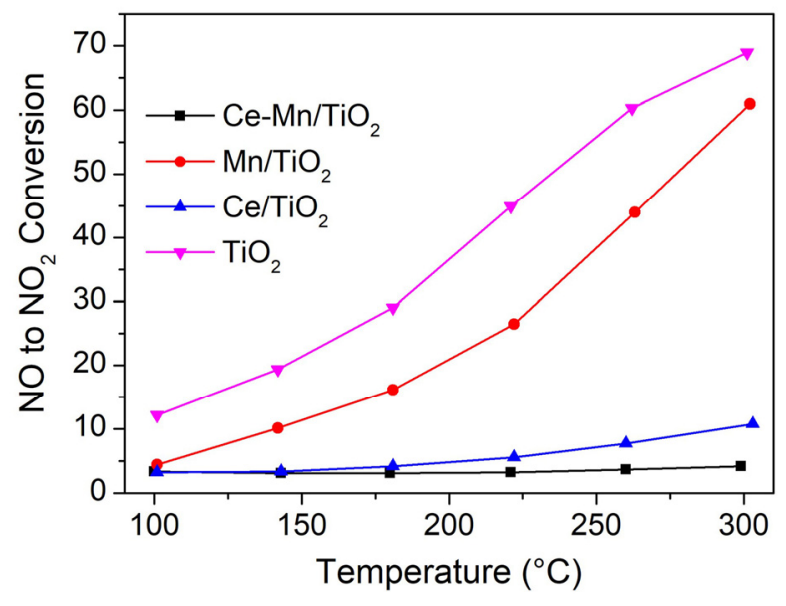

Fig. 2. NO oxidation activity test curves.

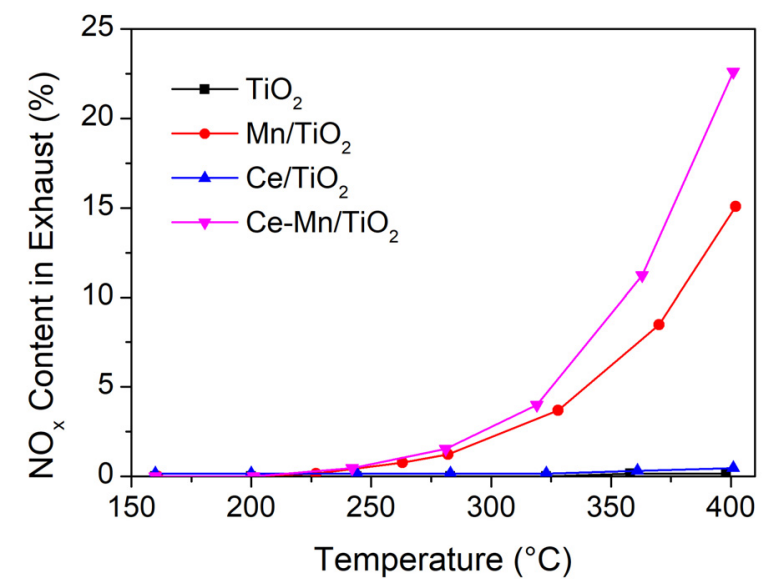

Fig. 3. $\mathrm{NH}_{3}$ oxidation activity test curves.

\subsection{Structure characteristic of catalysts}

To reveal the structure of catalysts and to construct the structure-activity relationship, XRD and XPS characteristics were conducted. The XRD patterns of the four samples are illustrated in Fig. 4. $\mathrm{TiO}_{2}$ support is made up of anatase $\mathrm{TiO}_{2}\left(2 \theta=25.3^{\circ}, 37.0^{\circ}, 37.8^{\circ}, 38.6^{\circ}\right.$, $48.1^{\circ}, 53.9^{\circ}, 55.0^{\circ}, 62.7^{\circ}, 68.9^{\circ}$ and $\left.70.3^{\circ}\right)$ and traces of rutile $\mathrm{TiO}_{2}\left(2 \theta=27.5^{\circ}\right)$, and there is no obvious effect on the $\mathrm{TiO}_{2}$ crystal structure with $\mathrm{MnO}_{\mathrm{x}}$ and $\mathrm{CeO}_{\mathrm{x}}$ loading. For the $\mathrm{CeO}_{\mathrm{x}}$ species, there are no characteristics peaks of $\mathrm{CeO}_{2}$ species in the XRD patterns of $\mathrm{Ce} / \mathrm{TiO}_{2}$ and $\mathrm{Ce}-$ 
$\mathrm{Mn} / \mathrm{TiO}_{2}$, indicating $\mathrm{CeO}_{\mathrm{x}}$ species is well dispersed on $\mathrm{TiO}_{2}$ support. For the $\mathrm{MnO}_{\mathrm{x}}$ species, the characteristic peaks of $\mathrm{MnO}_{2}\left(2 \theta=28.7^{\circ}, 42.7^{\circ}\right.$ and $\left.56.8^{\circ}\right)$ appear in the XRD pattern of $\mathrm{Mn} / \mathrm{TiO}_{2}$, but there are no peaks of $\mathrm{MnO}_{2}$ in the pattern of $\mathrm{Ce}-\mathrm{Mn} / \mathrm{TiO}_{2}$. These indicate the introduction of $\mathrm{Ce}$ can promote the dispersion of $\mathrm{MnO}_{\mathrm{x}}$. The surface element concentrations on the surface of catalysts detected by XPS are shown in Table 1 . The content of $\mathrm{Mn}$ atom increases from $2.79 \%\left(\mathrm{Mn} / \mathrm{TiO}_{2}\right)$ to $5.85 \%\left(\mathrm{Ce}-\mathrm{Mn} / \mathrm{TiO}_{2}\right)$ with the introduction of the $\mathrm{Ce}$ element, which can further prove that the dispersion of $\mathrm{MnO}_{\mathrm{x}}$ was improved with the dope of Ce. Meanwhile, the content of $\mathrm{Ce}$ atom in $\mathrm{Ce}-\mathrm{Mn} / \mathrm{TiO}_{2} \quad(2.70 \%)$ decreases compared with that in $\mathrm{Ce} / \mathrm{TiO}_{2}(2.41 \%)$, indicating that the $\mathrm{Ce}$ element could be doped in the $\mathrm{MnO}_{\mathrm{x}}$ species. Besides the dispersion of $\mathrm{MnO}_{\mathrm{x}}$, the effect of $\mathrm{Ce}$ on $\mathrm{Mn}$ ion valence state was also analysed. As shown in the Mn $2 p$ XPS spectra in Fig. 5, the peaks of Mn 2p3/2 were deconvoluted into three peaks at 642.0 $\mathrm{eV}, 641.0 \mathrm{eV}$ and $644.6 \mathrm{eV}$, corresponding to $\mathrm{Mn}^{4+}$, $\mathrm{Mn}^{3+}$ and $\mathrm{Mn}^{2+}$, respectively [4]. It can be seen that the content of $\mathrm{Mn}^{4+}$ were significantly increased with the dope of Ce element. It has been widely reported that the $\mathrm{Mn}$ ion with a high oxidation state ( such as $\mathrm{Mn}^{4+}$ ) is the main active species for NO oxidation process over $\mathrm{MnO}_{\mathrm{x}}$-based catalysts [13-15]. Therefore, the role of Ce over $\mathrm{Ce}-\mathrm{Mn} / \mathrm{TiO}_{2}$ catalyst can be assigned to two aspects: First, the introduction of $\mathrm{Ce}$ can promote the dispersion of $\mathrm{MnO}_{\mathrm{x}}$ on $\mathrm{TiO}_{2}$ support; Second, the dope of $\mathrm{Ce}$ in $\mathrm{MnO}_{\mathrm{x}}$ can increase the content of $\mathrm{Mn}^{4+}$, which possesses higher NO oxidation activity.

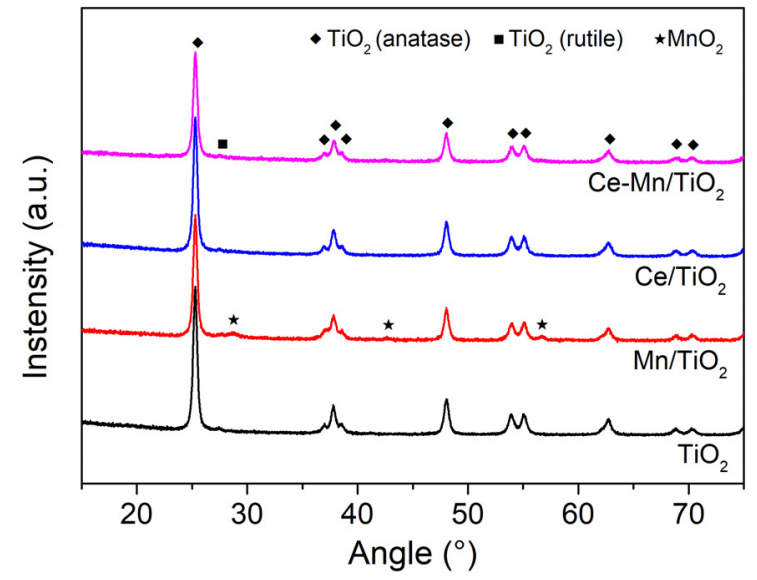

Fig. 4. XRD patterns of $\mathrm{TiO}_{2}, \mathrm{Mn} / \mathrm{TiO}_{2}, \mathrm{Ce} / \mathrm{TiO}_{2}$ and $\mathrm{Ce}-$ $\mathrm{Mn} / \mathrm{TiO}_{2}$ catalysts.

Table 1. Surface element content detected by XPS.

\begin{tabular}{ccccc}
\hline Catalysts & \multicolumn{5}{c}{ Surface atomic content (\%) } \\
& $\mathrm{Mn}$ & $\mathrm{Ce}$ & $\mathrm{Ti}$ & $\mathrm{O}$ \\
\hline $\mathrm{TiO}_{2}$ & -- & -- & 34.16 & 65.84 \\
$\mathrm{Ce} / \mathrm{TiO}_{2}$ & -- & 5.41 & 29.71 & 64.88 \\
$\mathrm{Mn} / \mathrm{TiO}_{2}$ & 2.79 & -- & 32.86 & 64.35 \\
$\mathrm{Ce}-\mathrm{Mn} / \mathrm{TiO}_{2}$ & 5.85 & 2.70 & 28.05 & 63.40 \\
\hline
\end{tabular}

\subsection{Study on the structure-activity relationship}

In the previous study [12], it has been found that a bidentate nitrate species of $\mathrm{MnO}_{2} \mathrm{NO}_{2}$ plays a crucial role over $\mathrm{NO}$ oxidation process, and the $\mathrm{MnO}_{2} \mathrm{NO}_{2}$ species can be decomposed to $\mathrm{NO}$ and $\mathrm{O}_{2}$ in $250-400{ }^{\circ} \mathrm{C}$. Therefore, in the temperature-programmed desorption (He-TPD) experiment of the reacted catalysts after the NO oxidation test, the amount of $\mathrm{MnO}_{2} \mathrm{NO}_{2}$ can be reflected by the amount of decomposed $\mathrm{O}_{2}$ in 250 $400{ }^{\circ} \mathrm{C}$. For this reason, the He-TPD experiments of the reacted $\mathrm{Mn} / \mathrm{TiO}_{2}$ and $\mathrm{Ce}-\mathrm{Mn} / \mathrm{TiO}_{2}$ after $\mathrm{NO}$ oxidation tests were conducted, and the corresponding $\mathrm{O}_{2} \mathrm{MS}$ signals are shown in Fig. 6. The peak area $\left(250-400{ }^{\circ} \mathrm{C}\right)$ in the $\mathrm{O}_{2} \mathrm{MS}$ curve of reacted $\mathrm{Ce}-\mathrm{Mn} / \mathrm{TiO}_{2}$ is about 5.6 times higher than that of reacted $\mathrm{Mn} / \mathrm{TiO}_{2}$. Meanwhile, according to the XPS results, the $\mathrm{Mn}^{4+}$ content in Ce$\mathrm{Mn} / \mathrm{TiO}_{2}$ is about 5.1 times higher than that in $\mathrm{Mn} / \mathrm{TiO}_{2}$. The comparability of these two values indicates that $\mathrm{Mn}^{4+}$ plays a crucial role in $\mathrm{MnO}_{2} \mathrm{NO}_{2}$ formation, thus $\mathrm{Mn}^{4+}$ is the active site for $\mathrm{NO}$ oxidation process.

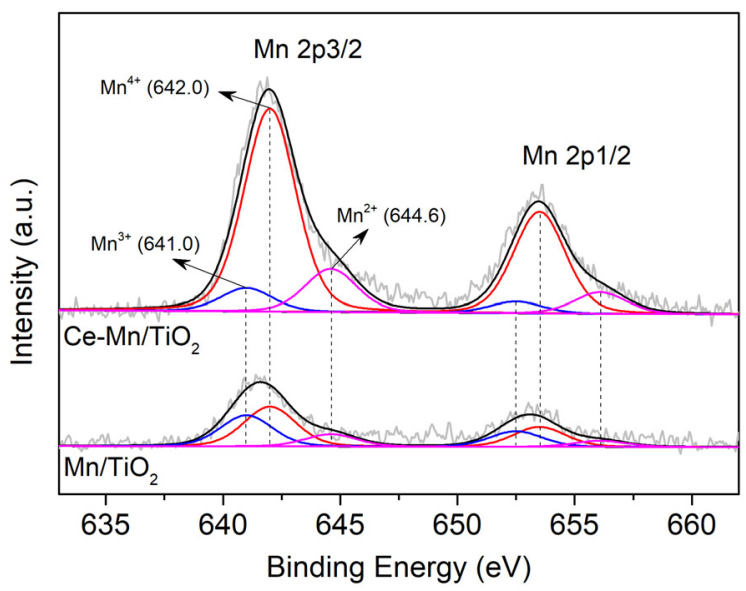

Fig. 5. Mn $2 p$ XPS patterns of $\mathrm{TiO}_{2}, \mathrm{Mn} / \mathrm{TiO}_{2}, \mathrm{Ce} / \mathrm{TiO}_{2}$ and $\mathrm{Ce}-\mathrm{Mn} / \mathrm{TiO}_{2}$ catalysts.

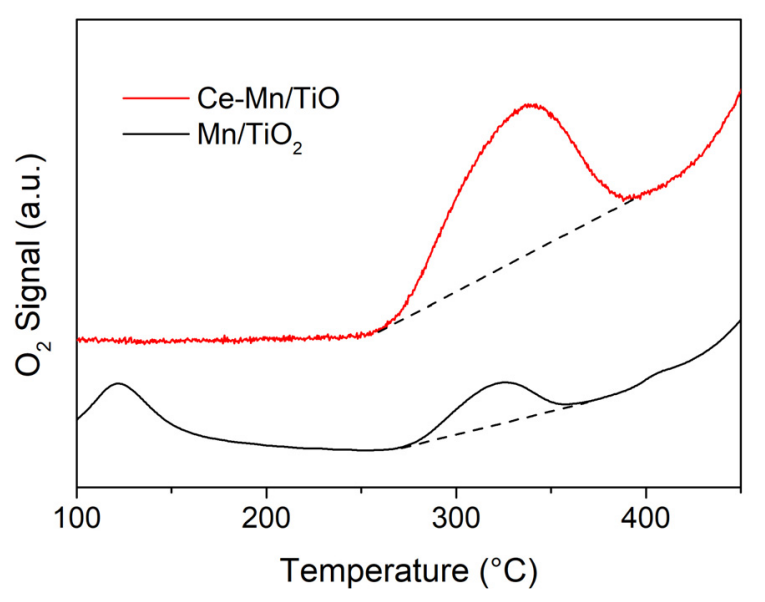

Fig. 6. $\mathrm{O}_{2} \mathrm{MS}$ signals in $\mathrm{He}-\mathrm{TPD}-\mathrm{MS}$ of the reacted $\mathrm{Mn} / \mathrm{TiO}_{2}$ and $\mathrm{Ce}-\mathrm{Mn} / \mathrm{TiO}_{2}$ after $\mathrm{NO}$ oxidation tests. 


\section{Conclusion}

In this work, a series of $\mathrm{Mn} / \mathrm{TiO}_{2}, \mathrm{Ce} / \mathrm{TiO}_{2}$ and $\mathrm{Ce}-$ $\mathrm{Mn} / \mathrm{TiO}_{2}$ catalysts were synthesized through incipientwetness impregnation method, and $\mathrm{Ce}-\mathrm{Mn} / \mathrm{TiO}_{2}$ exhibits robust $\mathrm{NH}_{3}$-SCR activity in low-temperature. Combined with XRD and XPS results, the positive role of Ce on $\mathrm{Ce}-\mathrm{Mn} / \mathrm{TiO}_{2}$ catalyst in the $\mathrm{NH}_{3}-\mathrm{SCR}$ process was revealed. First, the introduction of $\mathrm{Ce}$ can promote the dispersion of $\mathrm{MnO}_{\mathrm{x}}$ on $\mathrm{TiO}_{2}$ support; Second, the doping of $\mathrm{Ce}$ in $\mathrm{MnO}_{\mathrm{x}}$ can also increase the content of $\mathrm{Mn}^{4+}$ species. It was found that $\mathrm{Mn}^{4+}$ species plays a crucial role in NO oxidation process, which can trigger "Fast SCR" reaction and promote $\mathrm{NH}_{3}-\mathrm{SCR}$ process at lowtemperature. This work provides new insight into the catalyst design for $\mathrm{NH}_{3}$-SCR process at low-temperature.

\section{Acknowledgement}

This work was financially supported by the Fundamental Research Funds for the Central Universities (No. 18CX06070A).

\section{References}

1. C. Paolucci, I. Khurana, A. A. Parekh, S. Li, A. J. Shih, H. Li, J. R. Di Iorio, J. D. AlbarracinCaballero, A. Yezerets, J. T. Miller, W. N. Delgass, F. H. Ribeiro, W. F. Schneider, R. Gounder, Science 357, 898 (2017)

2. M. Zhu, J. -K. Lai, U. Tumuluri, Z. Wu, I. E. Wachs, J. Am. Chem. Soc. 139, 15624 (2017)

3. J. Yang, S. Ren, T. Zhang, Z. Su, H. Long, M. Kong, L. Yao, Chem. Eng. J. 379, 122398 (2020)

4. S. Deng, T. Meng. B. Xu, F. Gao, Y. Ding, L. Yu, Y. Fan, ACS Catal. 6, 5807 (2016)

5. F. Gao, X. Tang, H. Yi, J. Li, S. Zhao, J. Wang, C. Chu, C. Li, Chem. Eng. J. 317, 20 (2017)

6. L. Zhang, L. Li, Y. Cao, X. Yao, C. Ge, F. Gao, Y. Deng, C. Tang, L. Dong, Appl. Catal. B: Environ. 165, 589 (2015)

7. R. Jin, Y. Liu, Y. Wang, W. Cen, Z. Wu, H. Wang, X. Weng, Appl. Catal. B: Environ. 148-149, 582 (2014)

8. Z. Ma, L. Sheng, X. Wang, W. Yuan, S. Chen, W. Xue, G. Han, Z. Zhang, H. Yang, Y. Lu, Y. Wang Adv. Mater. 31, 1903719 (2019)

9. H. Chang, X. Chen, J. Li, L. Ma, C. Wang, C. Liu, J. W. Schwank, J. Hao, Environ. Sci. \& Technol. 47, 5294 (2013)

10. Z. Liu, G. Sun, C. Chen, K. Sun, L. Zeng, L. Yang, Y. Chen, W. Wang, B. Liu, Y. Lu, Y. Pan, Y. Liu, C. Liu, ACS Catal. 10, 6803 (2013)

11. Z. Liu, M. Wang, S. Liu, Z. Chen, L. Yang, K. Sun, Y. Chen, L. Zeng, W. Wang, J. Zhao, G. Sun, B. Liu, Y. Pan, Y. Liu, C. Liu, Appl. Catal. B: Environ. 269, 118731 (2020)

12. Z. Liu, C. Chen, J. Zhao, L. Yang, K. Sun, L. Zeng,
Y. Pan, Y. Liu, C. Liu, Chem. Eng. J. 379, 122288 (2020)

13. F. Kapteijn, L. Singoredjo, A. Andreini, Appl. Catal. B: Environ. 3, 173 (1994)

14. Meng D, Zhan W, Guo Y, Guo Y, Wang L, Lu G, ACS Catal. 5, 5973 (2015)

15. P. Sun, R. Guo, S. Liu, S. Wang, W. Pan, M. Li, Appl. Catal. A: Gen. 531, 129 (2017) 